The International Conference : Cities’ Identity Through Architecture and Arts (CITAA)

\title{
Policies, Strategies, and Mechanisms of New Cities in Egypt
}

DOI: $10.21625 /$ archive.v1i1.115

\author{
Esraa Osama Salem ${ }^{1}$, Miran Essam Monir ${ }^{2}$ \\ ${ }^{1}$ Lecturer, Architectural Department, Faculty of Fine Arts, Helwan University, \\ ${ }^{2}$ Lecturer Assistant, Architectural Department, October High Institute for Engineering \&Technology
}

\section{Keywords}

Policies, Strategies, Mechanisms, New cities, Development.

\begin{abstract}
The need to establish new cities emerged in the seventies of the last century in Egypt. The necessity emerged because of different reasons such as decreasing te pressure on greater cities and their infrastructure, creating new investments and job opportunities. Furthermore, it aimed to the rarefaction of the concentration of inhabitants around the narrow side of the Nile valley and its Delta. It even moved towards the vast desert in order to redraw the urban map of Egypt.

So, the success of these new cities is measured by how much people they attract to settle and their input to local income according to general policies and goals which could be achieved through several strategies and mechanisms.

Therefore, this research tries to discuss different policies in order to develop new cites, in particular, in addition to the efficient strategies and mechanisms which are necessary to decrease the consumption of resources and to achieve maximum benefits out of the available potentials.
\end{abstract}

\section{Introduction}

Egypt is affected by the accelerated urban growth of its great cities caused by the centralization of main activities and developments in these cities. It has led to the rapid increase of the population density and the increase of the demand to inhabit major cities. Thus, the idea of establishing new cities emerged accordingly, and it was initially referred to in law No. 59/ 1979, and in the economic and social development plan 1987/86-1983/82. In the latter, it identified the main objectives of their establishment, which have decreased the high population density and have easen the burden on existing areas or current cities. The solution was manily about heading to the Egyptian desert and coasts in order to establish new cities that absorb a portion of the overpopulation in different cities. Within the framework of a regional urban planning, emerging from general national planning, the entire process occured. And this was an indicator of a new phase in the state's commitment to reconstruct and formulate the development policies for new cities pertaining their strategies and mechanisms.

In the context of development efforts, undertaken by Egypt, the main research question is set, by the two researchers, who are going to seek its answer. The research question is: What are the most important followed policies in the development of new cities, of different types, and what are the proposed strategies and implementation mechanisms to achieve the aim of these policies so as to ensure the achievement of the real development of the new cities in Egypt? 


\section{Development:}

Development is considered as the first aim sought by all countries to improve the conditions of their new cities, Thus, it is considered both, the aim and the means at the same time (Human Development Report, 2005). Development includes, implicitly, the concepts of Growth and Change, which should be implemented by the means of quality and quantity simultaneously, in the social, cultural and economic aspects, as no development can exist without growth. However, development refers to the resulting changes in the growth process (Hart Environmental Data, 1998). There are two standards, considered as the base in measuring and assessing development (Mohammed Abd Elmoniam, 2008).

\subsubsection{Demographic Standard (Population Study):}

Expressed by the direct relation between the population numbers and the development inside a new city; as the population increases in this city, it refers to the abundance of the services and job opportunities referring to the increase of the developmental rates in it. ${ }^{1}$

\subsubsection{Economic Standard (Economic Study):}

It includes investments, economic base, and employment. The increase of the investments refers to the high developmental rates, where the economic base is the most important economic factor because a diversified economic base means diversity of economic activities in the city. It attracts the largest number of inhabitants and thus resulting in its development. In addition to a group of other factors represented in the urban, administrative and service standards (Quality of life). ${ }^{2}$

\section{Classification of Development:}

Development is classified according to its 4 main dimensions; economic, social, political and urban development. It is also classified according to its main types into a comprehensive and a sectoral development.

\subsection{According to its main types:}

Development is classified into two main types, which are comprehensive and sectoral development, as follows:

\subsubsection{Comprehensive Development:}

It is a development that has a general comprehensive main aim, which occurs in society. Its aspects are clear in the structural and functional changes that occur in the society aiming to achieve the desired social and economic welfare for all its individuals. ${ }^{3}$

\subsubsection{Sectoral Development:}

It is a development that deals with every and each developmental aspect as an individual entity. This type of development focuses on a developmental aspect or a single issue, and it is concerned with its related policies. It may focus on the housing or the urban sector as an example. ${ }^{4}$

\subsection{According to the main dimensions:}

It is classified according to the main dimensions concerning the economic, social, political and urban development.

\section{$\underline{\text { Development Classification }}$}

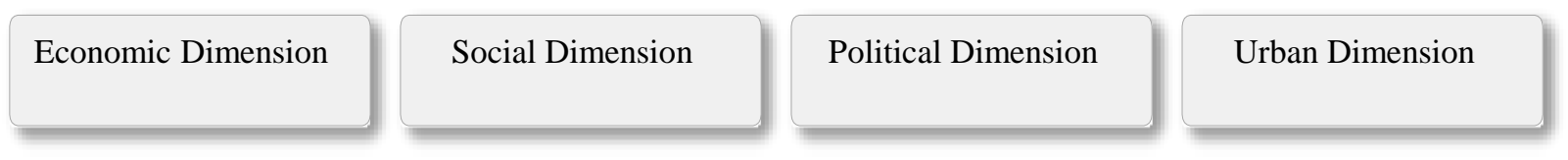

Figure 1: Shows the classification of development in accordance with the main dimensions and the main types. Source: (Heba Saif al-Islam, 2012)

\footnotetext{
${ }^{1}$ Eng. Mohammed Nabil Abdel Moneim, Development of new urban communities, "The Egyptian State and International Experiences," Master Thesis (Faculty of Engineering: Cairo University, 2008) 


\subsubsection{Economic Dimension:}

This sector is concerned with the physical dimensions of the development process. It is sometimes called development economics. It seeks to confine the material resources of the community and to establish a list of priorities and alternatives raises in order to reach a particular purpose. That is shown through the traditional economic variables such as income, consumption, and investment.

\subsubsection{Social Dimension:}

This dimension is concerned with the in-human elemens, like education, training and acquiring experience to become an assistant element that supports the development programs, not apposing them.

\subsubsection{Political Dimension:}

This dimension is concerned with the development of the political system to be more effective in the development process, like taking developmental decisions stemmed from a realistic understanding of the economic potential of the community and a detailed analysis of its social structure.

\subsubsection{Urban Dimension:}

This dimension is concerned with the spatial dimension for the achievement of social and economic development according to a comprehensive developmental plan.

For the success of the development process, it must be carried out in the context of a plan based on the integration of the main development aspects (Wakil, 2006): Economic Development: Including investments and exploitation of resources, Social Development: Including education, health, recreation and Culture, Political Development: Including development decisions.

The integration between the previous three elements directly affects the urban development, which includes areas of investment and services, as it is the inclusive vessel for development.

\section{New Cities:}

The establishment of new cities in Egypt was carried out in successive phases leading to the emergence of three generations of the new cities as follows:

First generation: 6th October City, Tenth of Ramadan, Sadat City,15 May City, New Borg El Arab, New Salehia, New Damietta and Touristic Villages, Second generation: Sheikh Zayed City, Oubour City, Badr City, New Noubarya, New Beni Suef and New Minya ,and Third generation: Rehab, El Sherouk, New Cairo, New Assuit, Tiba, New Sohag, New Aswan, New Qena, New Fayoum and New Akhmim. ${ }^{5}$

The basic considerations behind the creation of new cities vary according to the various systems and social, economic and environmental conditions. At the same time, these cities are considered as a reflection of certain concepts.

\subsection{Distribution of new cities in Egypt: Distributing of new cities in Egypt as follows:}

Eight cities surrounding or nearby Greater Cairo region, they are: (Tenth of Ramadan, May 15, 6th of October, Badr, Oubour City, Sheikh Zayed, El Sherouk and New Cairo), Six new cities in Lower Egypt: (Sadat City, Arab tower, Salehia, New Damietta, Noubarya), Four cities in upper Egypt : (New Beni Suef ,new Minya, New Assiut, New Tiba, and three new cities under construction in Upper Egypt : (New Sohag, New Aswan , Toshka) ${ }^{6}$

\footnotetext{
${ }^{5}$ Dr. Ahmed Mohammed Abdel Aal. A Book of New Cities and Regional Development in Egypt, Magazine of the Faculty of Arts, Minya University, 1992.

${ }^{6}$ Eng. Mohammed Nabil Abdel Moneim, Development of new urban communities, "The Egyptian State and International Experiences," Master Thesis (Faculty of Engineering: Cairo University, 2008)
} 


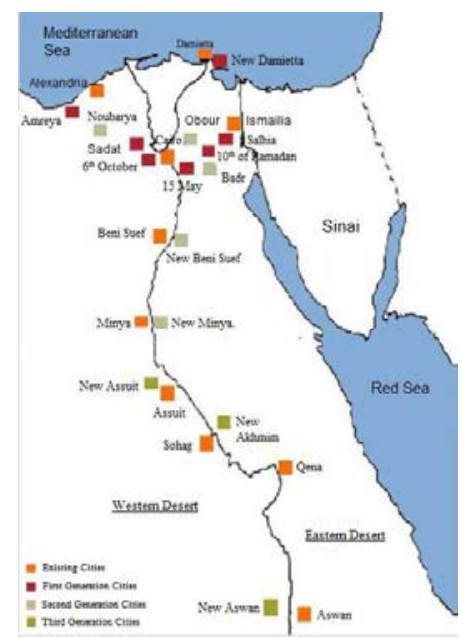

Figure 2: an Illustrative map for the distribution of new cities in Egypt, according to three generations. Source: the two researchers

\subsection{Classification of new cities in Egypt:}

Numerous classifications of the new cities exist, sometimes according to the construction site, function or selfsufficiency, or according to the role of the new city in the development, etc. These could be summarized into 3 classifications: the first is according to the construction site and function: Satellite towns, Self - supported and Twins towns. The second is classified according to self-sufficiency: Town with self-sufficient economy and Towns without a self-sufficient economy and the third is according to its role in development: Growth centerpoles, Relief poles, National projects cities and towns multiple targets.

\subsubsection{Classification according to the construction site and function:}

New cities can be classified in terms of function and construction site into 3 main types: Satellite towns, Self supported, and twins town (Abdel Moneim, 2008), as follows:

\subsubsection{Satellite towns:}

They are located around the mother town or near it, and sometimes it aims to both the short and mid- term to lessen the population densities for this city. It also takes advantage of the existing infrastructure if they are available. These cities do not have an economic base, and its location near the mother town has encouraged urban sprawl to reach them.

\subsubsection{Twin cities:}

They are located adjacent to existing urban cities, sometimes considered as natural extension for these cities and they are nothing more than residential areas that have no economic base or pillar.

\subsubsection{Self- supported cities:}

They are far away from the existing cities by a distance that requires self-support, and they have an economic base that aims in the long term to the creation of economic growth poles from independent economic entities.

\subsubsection{Classification according to self-sufficiency into 2 main types (Abdel El Qader, 2005):}

\subsubsection{Towns with the self-sufficient economy:}

They are based on the presence of an economic base, so the residents can satisfy all their daily needs within the cities' borders, in addition to the produced services and goods, which can be exported to neighboring provinces. ${ }^{7}$

\subsubsection{Towns without self-sufficient economy:}

They are the familiar cities, or the most prevalent, as they are the cities close to the main city and have economic and urban growth linked to an existing urban center. It represents an integral part of its economic aspect. They are close to the mother city to guarantee daily visits (are independent organically and economically dependent). ${ }^{8}$

\footnotetext{
${ }^{7}$ Eng. Lamya Ahmed Abdel-Qader. An Analytical Study of the Problems of Development in the New Cities in Egypt, Master Thesis (Cairo University: Faculty of Engineering, 2005).

${ }^{8}$ PID
} 


\subsubsection{Classification according to its role in development/construction aim:}

The role of the city in development means its functional role that contributes to solving the problem of population and regional development, thus we can classify new cities according to their role in the development / the objective of the construction, into three main types, as follows (Abdul Aal, 1992): ${ }^{9}$

\subsubsection{Growth center - poles:}

It aims to select a limited number of areas which have the potential of social and economic growth to intensify the development elements in order to turn these areas into growth poles for the surrounding areas. They grow themselves first, and then through the development diffusion, spread, development crawls through these areas as well.

\subsubsection{Relief poles:}

These cities aim to lessen the population and the economic pressure on all major satellite cities, in addition to the development of the suburbs.

\subsubsection{National projects cities and multi-purpose cities:}

all cities of national projects are located in desert areas with an economic potential valid for establishing an economic project.

\section{Policy:}

The broader definition of policy is: "A framework for action in order to achieve a particular goal with supervision and interest." The policy is characterized by diversity, inclusion, and penetration that affects all aspects of life in a society. In addition, the implementation of this policy is set in accordance with specific strategies and mechanisms that allow them to exploit resources and facilities available for achieving the target of planned policy. ${ }^{10}$

\subsection{Main policies for the development of new cities:}

New cities development policies in Egypt are summarized in the three main types, as follows:

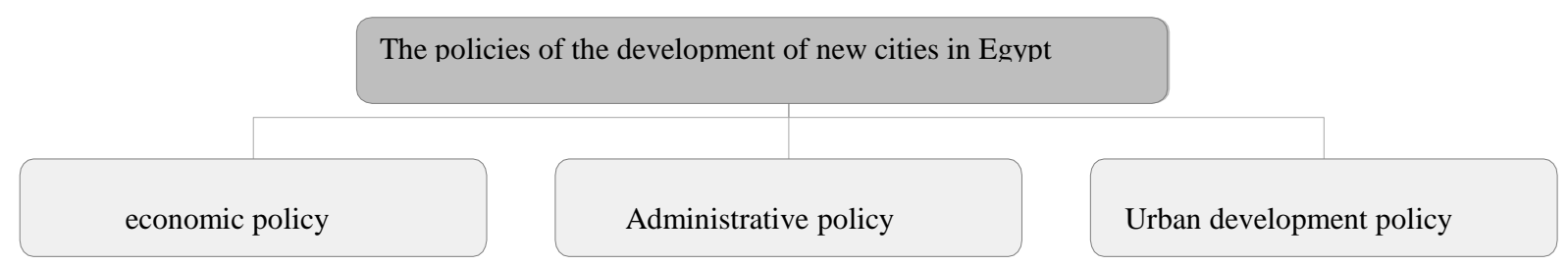

Figure 3: Illustrates development policies in new cities in Egypt. Source: Eng. Lamya Ahmed Abdel-Qader. An Analytical Study of the Problems of Development in the New Cities in Egypt, Master Thesis (Cairo University: Faculty of Engineering, 2005).

\subsubsection{Urban development policy for new cities in Egypt:}

The state set an inclusive urban development plan aiming to reshape the demographic map of Egypt in order to achieve the requested balance between the growing population numbers and available areas of land, while ensuring the optimization of the use of natural and economic potentials that are available on three main axes simultaneously in terms of the planning concept, even if they vary in terms of the time zone implementation, as follows:

Table 1. Illustrates the basic axes of the main policy of urban development in Egypt. Source: Dr. Ahmed Mohammed Abdel Aal. A Book of New Cities and Regional Development in Egypt, Magazine of the Faculty of Arts, Minya University, 1992.

\begin{tabular}{|l|l|}
\hline \multicolumn{2}{|c|}{ Main axes for urban development policy in Egypt } \\
\hline 1 & Creating a set of new cities in desert areas (three generations of cities) \\
\hline
\end{tabular}

\footnotetext{
${ }^{9}$ Dr. Ahmed Mohammed Abdel Aal. A Book of New Cities and Regional Development in Egypt, Magazine of the Faculty of Arts, Minya University, 1992.

${ }^{10}$ Dr. Sodfa Mohamed Mahmoud and Nagwan Farouk Shiha. The International Conference on Public Opinion Polls and Decision-making". Published paper entitled: The Role of Public Opinion Polls in Policy-making, 2007.
} 


\begin{tabular}{|c|l|}
\hline 2 & $\begin{array}{l}\text { Development and urbanization of some of the areas of the Republic that have } \\
\text { not received sufficient amount of attention before }\end{array}$ \\
\hline 3 & Re-planning of the major cities and important urban centers \\
\hline
\end{tabular}

\subsubsection{Administrative policy for new cities in Egypt:}

The current method of urban management in new Egyptian cities is considered as an executive management meaning a centralized management, which is used at all the levels of the state. It intends to implement plans in the framework of the proposed financing from the state's budget and in a time-bound framework. It should allow for the transition of the execution of other projects; however, the interactive administration is characterized by flexibility and independence in decision-making. The implementation of its goals in a convenient method with the circumstances and variables affect new cities. The most important objective of the interactive management is to achieve balance between human settlements, settlement services and industrial settlements. ${ }^{11}$

\subsubsection{Policy (economic trends) for the development of new cities in Egypt:}

The economic trends for the development of new cities in Egypt are summarized into three main themes, as follows:

\subsubsection{The full responsibility of the State for development, with a limited role for the private sector:}

The responsibility of a single side for an integrated and coordinated development, along with carrying out some of the contributions that could be carried out by supporting sides such as the private sector, thus, this side should have access to a huge amount of technical and financial resources that can only be provided by the state, leading to in the development budget for new cities. ${ }^{12}$

\subsubsection{Presentation new cities as open areas for investment:}

New cities are open to specialized investors in the fields of urban development fields, to be administered by the private sector in all its forms, in addition to the presence of governmental agencies in the form of planning systems, whose role is limited to the control and supervision of urban development systems in new cities. ${ }^{13}$

\subsubsection{The disciplined partnership between the private sector and government:}

Through independent sides that carry out development in the new cities in accordance with a declared previous planning so that these actors perform their role in development as a catalyst for development. It requires providing the required power for its own development process in accordance to its economic vision seen in light of a general plan for the state. ${ }^{14}$

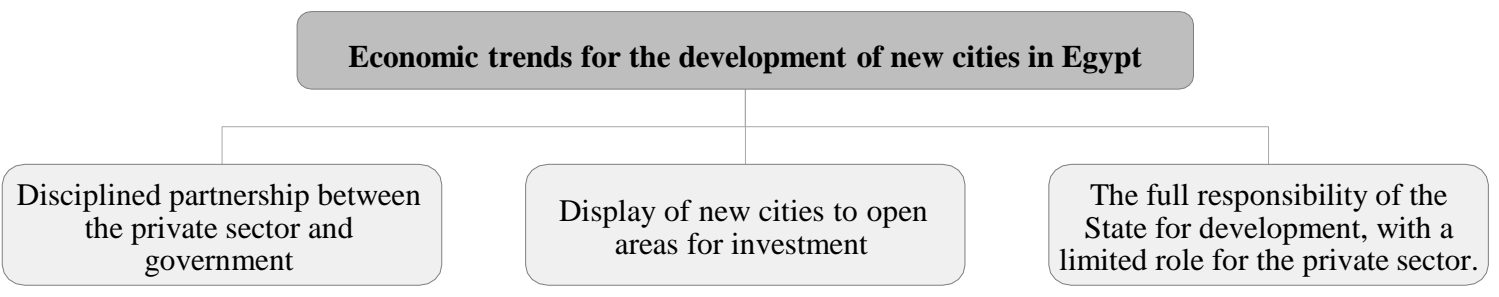

Figure 4: Illustrates the economic trends for the development of new cities in Egypt. Source: Eng. Mahmoud Amin. The Functional Roles of Cities and New Communities within the Framework of National and Regional Policies Comprehensive Urban Development. Published paper entitled: The International Congress of the policies of the New Urban Communities Development, Alexandria Library in 2009.

\section{Strategies and mechanisms of the development of new city:}

The Development strategies and mechanisms are considered two essential engines to achieve the goal of planned policy, defining the detailed working method to its achievement. There is no policy without a strategy that allows

\footnotetext{
${ }^{11}$ Eng. Mahmoud Amin. The Functional Roles of Cities and New Communities within the Framework of National and Regional Policies Comprehensive Urban Development. Published paper entitled: The International Congress of the policies of the New Urban Communities Development, Alexandria Library in 2009.

${ }^{12}$ PID

${ }^{13}$ Eng. Mahmoud Amin. The Functional Roles of Cities and New Communities within the Framework of National and Regional Policies Comprehensive Urban Development. Published paper entitled: The International Congress of the policies of the New Urban Communities Development, Alexandria Library in 2009.

${ }^{14}$ PID
} 
its implementation through benefiting from the available resources and potentials available as much as possible (9th International Engineering Conference - Al Azhar, 2007) as follows:

\subsection{Development Strategies:}

The strategy is defined as "The art of exploitation of available potentials and possibilities for the implementation of certain policy, and it is a thinking pattern to pave the way toward a very specific aim of the strategy". A strategy for establishing new cities aims to the distribution of the inhabitants and various activities. There are seven strategies for the development of new cities: water strategy, a strategy for agricultural development, industrial development strategy, the strategy of tourism development, and the social development strategy, a strategy for attracting the population and a strategy for urban development, as follows: ${ }^{15}$

\subsubsection{Water strategy:}

one of the most fundamental strategies included in developmental plans, and those plans cannot be achieved without the search for a source of water through the development of irrigation systems. It workds through using groundwater, re-using agricultural drainage water and re-using sewage water.

\subsubsection{Agricultural development strategy:}

It is ranked first in the strategies after the water strategy due to the vital and major role of agriculture in the developmental processes through the selection of appropriate crops for the type of soil, climate and water shortage, choose crops with large profits and the best seed strains of seed to maximize the investment process, in addition to use of modern equipment in agriculture, establishing areas of open grazing, accurately employing the crop typed to serve industries that can be established in the region.

\subsubsection{Industrial development strategy:}

It is one of the most important strategies that support the economic activities through establishing factories in sites with available materials to reduce transportation. It depends on exporting, in addition to upgrading the technological level of the community and the expansion of the participation of the private sector in the industry's development.

\subsubsection{Tourism development strategy:}

One of the most important strategies that support economic activities, and one of the national alternatives for agricultural and industrial development. It varies according to the available type of tourism, and it is concerned with establishing places of relaxation such as hotels and campsites for those who seek tranquility or enjoying unique natural areas.

\subsubsection{Social development strategy:}

One of the most important strategies that support the development, and aims primarily at the individual development. This strategy is concerned with driving the populations to new communities, convincing and encouraging them to settle there and create the conditions that ensure their stay in these new places.

\subsubsection{Population attraction strategy:}

It is the main axe of the development process through economic attraction factors, such as job opportunities and rewarding salaries. In addition to the social attraction factors such as providing adequate housing for young married people and those seeking marriage, especially for those who can't afford adequate housing in their original city, in addition to providing means of security, safety, education, health and entertainment for new residents.

\subsubsection{Urban Development Strategy:}

It could be achieved by avoiding the establishment of urban communities in arable areas, or those containing mineral resources, or in sand dunes, storm water drains, or protectorates. The design of buildings must consider harsh climate conditions of heat and humidity through selecting convenient building materials and a suitable design concept for the environment.

\subsection{Development Frameworks:}

The development mechanism in the new cities is represented in the form of kinetic mechanism, combined to form a single developmental system. Thus, it is defined as "an integrated and detailed working method through goals, policies, and strategies". There are 14 mechanisms used and stated bellow:

\footnotetext{
${ }^{15}$ Eng. Ali M. Abbas, Azhar Ninth International Engineering Conference. Published paper entitled: The Development of Cities and Regions Random, 2007
} 
The mechanism of the basic pillars, the mechanism of exploitation, the mechanism of employment of natural resources, The mechanism of diversity, The mechanism of convergence, The mechanism of belonging, The mechanism of participation, The mechanism of sustainability, The mechanism of activating the movement of population, The mechanism of decentralization, The mechanism to maximize the consistency of the interaction, The mechanism civil and social aspects, The mechanism of industrial \& technological aspects, The mechanism of legislation and management. ${ }^{16}$

Table 2.Table 2: Shows the development mechanisms for new cities. Source: by the two researchers from Eng. Ali M. Abbas, Azhar Ninth International Engineering Conference. Published paper entitled: The Development of Cities and Regions Random, 2007.

\begin{tabular}{|c|c|}
\hline Mechanism & How to get the mechanism ( description ) \\
\hline $\begin{array}{l}6.2 .1 . \\
\text { Basicsupports }\end{array}$ & $\begin{array}{l}\text { The mechanism of the basic supports depends on the following: } \\
\text { Diagnosis of the current situation socially, culturally economically, and urban-wise and } \\
\text { identifying buildings' conditions and occupancy rates and extent of the need for additional } \\
\text { elements of the infrastructure. } \\
\text { To study the organic relationship between each city and its surrounding design and planning } \\
\text { regions, in terms of productive activities and relationships to form an economic, social and } \\
\text { cultural unity with the surrounding environment. } \\
\text { Training and rehabilitation of the citizens and organizing institutions and civil organizations } \\
\text { with developmental or social objectives or specific productivity that forms the hidden } \\
\text { dimension of management, follow-up, planning and public control, with no conflict, but rather } \\
\text { supports and integrates with government systems responsible for the central development. } \\
\text { Developing activities and functions that maximize the ability of new cities to attract residents } \\
\text { and increase the public city income. }\end{array}$ \\
\hline $\begin{array}{l}6.2 .2 . \\
\text { Coloniation }\end{array}$ & $\begin{array}{l}\text { The exploitation of arable land through classification according to the type of soil and selecting } \\
\text { suitable plants for the conditions of each type. } \\
\text { Exploitation of mineral wealth that is found in most of the Egyptian desert adjacent to new } \\
\text { cities, through the creation of many industries, such as limestone suitable for the manufacture } \\
\text { of cement, pure lime and the desert argil that is used in manufacturing clay brick, refractories } \\
\text { and ceramics, in addition to white sand, which is suitable for the manufacture of glass, basalt } \\
\text { rocks suitable for the manufacture of rock bricks and road pavements, and phosphate, used for } \\
\text { the manufacture of fertilizers. }\end{array}$ \\
\hline $\begin{array}{l}\text { 6.2.3.Resoures } \\
\text { Occupation }\end{array}$ & $\begin{array}{l}\text { The mechanism of resources employment is focused on : } \\
\text { Thorough understanding of the potential of the resources and putting them in the right place. } \\
\text { For example establishing factories on arable lands are forbidden, and areas rich in historical } \\
\text { elements should not be used for agricultural. } \\
\text { Following accurate scales to measure the inputs and outputs to achieve minimum losses against } \\
\text { biggest gains. }\end{array}$ \\
\hline
\end{tabular}




\begin{tabular}{|c|c|}
\hline $\begin{array}{c}\text { 6.2.4. } \\
\text { Diversification }\end{array}$ & $\begin{array}{l}\text { Including: } \\
\text { Diversifying of activity areas as depending on single elements is deplorable and doesn't } \\
\text { achieve inclusiveness and communication. } \\
\text { Diversifying the economic base allows for releasing the working energies in a better way. } \\
\text { Opening continuous development areas depending on agriculture, industry, tourism, and } \\
\text { others, according to the circumstances of each city. }\end{array}$ \\
\hline $\begin{array}{l}6.2 .5 . \\
\text { Diversification }\end{array}$ & $\begin{array}{l}\text { Through: } \\
\text { Developing the means of transportation and reducing the distances between new cities to } \\
\text { eliminate the isolation between them and the old valley, through some main axes, including: } \\
\text { Major road axes: represented in strengthening the wild axes, connecting new cities with the } \\
\text { old valley and connecting these cities together, in addition to providing links and additional } \\
\text { ways to enhance the connection. } \\
\text { Air transportation hubs: represented in developing the existing airports and establishing new } \\
\text { ones. } \\
\text { Telecommunications hubs: depends on the establishment of a network of modern } \\
\text { communication lines. }\end{array}$ \\
\hline $\begin{array}{l}\text { 6.2.6. } \\
\text { Attribution }\end{array}$ & $\begin{array}{l}\text { Through: } \\
\text { Promoting the sense of human belonging and participating in reclamation, construction, } \\
\text { construction management of different projects in the new cities. } \\
\text { As human is the main element in the establishment of new cities, preferably young elements } \\
\text { with different skills, whose engagement with their new communities can be a new beginning } \\
\text { to perform through a real sense of belonging. } \\
\text { The researcher believes that the mechanism of belonging is not realized unless there is } \\
\text { stability (social and economic) in the same place, in addition to participation to promote the } \\
\text { sense of belonging. }\end{array}$ \\
\hline $\begin{array}{l}\text { 6.2.7. } \\
\text { Participation }\end{array}$ & $\begin{array}{l}\text { The mechanism of participation is achieved through: } \\
\text { The involvement of the private sector and different organizations, even individuals in the } \\
\text { development process. } \\
\text { The participation process is done through } 2 \text { levels, a material one, through participation with } \\
\text { capital, and a moral one, by participation in the management and operational matters which } \\
\text { requires activation of the principle of direct free election of competencies, that are capable of } \\
\text { managing the affairs of investing institutions, thus, restructuring many administrative units } \\
\text { that form the administrative body system, leading to facilitation of the voluntary involvement } \\
\text { process for individuals to achieve the change they aspire. }\end{array}$ \\
\hline $\begin{array}{l}\text { 6.2.8. } \\
\text { Sustainability }\end{array}$ & $\begin{array}{l}\text { Through: } \\
\text { The pursuit and follow up of the development process, as the concept of sustainability means } \\
\text { communication and continuity. } \\
\text { Thus, it is not enough to carry out the development process without being able to maintain its } \\
\text { continuity, as sustainability is based on a foundation of non-crumbling resources, where the } \\
\text { vast majority of these resources can be recycled indefinitely. }\end{array}$ \\
\hline
\end{tabular}




\begin{tabular}{|c|c|}
\hline $\begin{array}{l}\text { 6.2.9. } \\
\text { Population } \\
\text { Movement }\end{array}$ & $\begin{array}{l}\text { The population movement is activated and residents are encouraged to move towards new } \\
\text { communities, through: } \\
\text { Providing strong attraction elements (economic, social and services), providing uniqueness of } \\
\text { jobs, efficient performance, and abundance of salary. } \\
\text { Providing job opportunities and rewarding salaries, is fundamental for activating the attraction } \\
\text { towards new cities, as the individual must prefer this place to others. } \\
\text { The submission of the process of attraction to the election of the working elements is } \\
\text { preferable, as young people are preferred due to their ability to benefit the community and } \\
\text { settle, forming families, with a sense of belonging to the place, as no community or } \\
\text { development can be found, without its inhabitants. }\end{array}$ \\
\hline $\begin{array}{l}\text { 6.2.10. } \\
\text { Decentralizatio } \\
\mathrm{n}\end{array}$ & $\begin{array}{l}\text { Means the transmission and distribution of functions from a central authority, or in other } \\
\text { words, distributing and directing national potentials from the central government and its } \\
\text { systems to the local authorities, through: } \\
\text { Providing fundamental foundation points as sub-capitals for new cities to be a substitute for } \\
\text { the mother capital, so that decision making and its consequences can be performed through } \\
\text { them. } \\
\text { Building administrative cadres capable of taking responsibility. } \\
\text { Taking into consideration that the new communities and cities are located in desert regions } \\
\text { that are distant from the central authority, the process of liberation from the central } \\
\text { constraints will push the development process forward where the decision making process } \\
\text { will be faster to face any problems or emergent obstacles. Freedom from centralized } \\
\text { decision-making doesn't mean secession from the general plans of the state, but rather, it } \\
\text { performs according to the pre-set system. }\end{array}$ \\
\hline $\begin{array}{l}\text { 6.2.11. } \\
\text { Interaction } \\
\text { amplification }\end{array}$ & $\begin{array}{l}\text { It means the mechanisms used to take advantage of modern and cutting-edge ideas, whether } \\
\text { in the field of technology or management and organization, for the success of development } \\
\text { projects in new cities. This is done through: } \\
\text { Clean energy technologies: } \\
\text { Where access to clean energy can be expanded, such as solar energy, due to the presence of } \\
\text { sun light around the year in the areas of new cities, in addition to the abundance of wind } \\
\text { energy in the desert. It should be noted that solar energy can be exploited during the day in } \\
\text { the sunrise, while, wind energy decreases during the day, and is more active at night, leading } \\
\text { to the idea of integration between the two systems. Thus, they can be harnessed to provide } \\
\text { cities with a clean energy supply that causes no environmental pollution. } \\
\text { Supporting projects, through providing technologically and organizationally advanced } \\
\text { services, so that all the means of initiating and embracing projects could be provided in an } \\
\text { integrated work system, to overcome the problems that lead to their failure. }\end{array}$ \\
\hline
\end{tabular}




\begin{tabular}{|c|c|}
\hline $\begin{array}{l}\text { 6.2.12. Civil } \\
\text { and social } \\
\text { aspects }\end{array}$ & $\begin{array}{l}\text { This includes: } \\
\text { - Co-ordination of work between the civil organizations, interested in the development of } \\
\text { new cities and their classification into groups according to the interest such as health, } \\
\text { society, and small projects. } \\
\text { - Enhancing the role of NGOs and civil society organizations in spreading the concepts of } \\
\text { preserving the natural resources such as water, air, soil, and energy sources. } \\
\text { • Establishing regional systems of certain environmental services, such as health burial of } \\
\text { solid waste or safe disposal of wastes of all kinds. } \\
\text { - Directing on supporting projects and research, which aims for the development of new } \\
\text { cities. } \\
\text { - Focus on the role of women in urban environmental protection as a source of awareness } \\
\text { within the family. } \\
\text { - Focus on development programs that provide direct services to help people settle in new } \\
\text { cities, especially young ones. } \\
\text { Coordinating efforts between the associations and organizations involved in urban development. }\end{array}$ \\
\hline $\begin{array}{l}\text { 6.2.13. } \\
\text { Industrial \& } \\
\text { technological }\end{array}$ & $\begin{array}{l}\text { Through: } \\
\text { - Restructuring industrial production regionally, allowing the industrial excellence of each new } \\
\text { city, according to its regional resources, whether they are human or natural resources. } \\
\text { - Encouraging small and medium industries in new cities. } \\
\text { - Using the means of economic stimulation, such as technical support, tax exemptions and } \\
\text { facilitated funding systems. }\end{array}$ \\
\hline $\begin{array}{l}\text { 6.2.14. } \\
\text { Legislation \& } \\
\text { management }\end{array}$ & $\begin{array}{l}\text { Through: } \\
\text { Liberalization of financing methods of the developmental projects in new cities. } \\
\text { Liberalization of labor heads of the central leaders and centralized decision making processes. } \\
\text { Legalization of certain activities and uses of new cities and activating laws related to the } \\
\text { prohibition of establishing structures and industrial activities inside or near urban communities. } \\
\text { The provision of the required land for various activities, in addition to the provision of } \\
\text { facilities, incentives, and exemptions to speed up the development process. }\end{array}$ \\
\hline
\end{tabular}

\subsection{The relation between development strategies and mechanisms:}

The relationship between development strategies and mechanisms is clarified through the following table:

Table 3.Shows the relation between the strategies and mechanisms of new cities development, by the two researchers

\begin{tabular}{|c|c|c|c|}
\hline Strategy & $\begin{array}{l}\text { Sources and } \\
\text { Possibilities }\end{array}$ & $\begin{array}{l}\text { The Required } \\
\text { Mechanism }\end{array}$ & $\begin{array}{l}\text { Work style for achieving the mechanism, is } \\
\text { done through: }\end{array}$ \\
\hline $\begin{array}{l}\text { Water } \\
\text { strategy }\end{array}$ & $\begin{array}{l}\text { The development of } \\
\text { irrigation systems and } \\
\text { the use of groundwater. } \\
\text { - Re-use of agricultural } \\
\text { drainage water, } \\
\text { residential and industrial } \\
\text { wastewater, to irrigate } \\
\text { forests and wooden } \\
\text { fruitless trees and that } \\
\text { does not harm public } \\
\text { health. }\end{array}$ & $\begin{array}{l}\text { Sustainability } \\
\text { Mechanism }\end{array}$ & $\begin{array}{l}\text { - Continuity and follow up of the development } \\
\text { process, as the concept of sustainability } \\
\text { means communication and continuity. } \\
\text { Thus, it is not enough to carry out the } \\
\text { development process without being able to } \\
\text { maintain its continuity, as sustainability is } \\
\text { based on a foundation of non-crumbling } \\
\text { resources, where the vast majority of these } \\
\text { resources can be recycled indefinitely. }\end{array}$ \\
\hline
\end{tabular}




\begin{tabular}{|c|c|c|c|}
\hline \multirow[b]{3}{*}{$\begin{array}{l}\text { Agricultural } \\
\text { development } \\
\text { strategy }\end{array}$} & \multirow{3}{*}{$\begin{array}{l}\text { - Selection of } \\
\text { appropriate crops for the } \\
\text { type of soil, climate and } \\
\text { water shortage, choose } \\
\text { crops with large profits } \\
\text { and the best seed strains } \\
\text { of seed } \\
\text { - to maximize the } \\
\text { investment process. } \\
\text { - Use of modern equipment } \\
\text { in agriculture, establishing } \\
\text { areas of open grazing, } \\
\text { accurately employing the } \\
\text { crop typed to serve } \\
\text { industries that can be } \\
\text { established in the region. }\end{array}$} & $\begin{array}{l}\text { Colonization } \\
\text { mechanism }\end{array}$ & $\begin{array}{l}\text { - The exploitation of arable land through } \\
\text { classification according to the type of soil } \\
\text { and selecting suitable plants for the } \\
\text { conditions of each type. }\end{array}$ \\
\hline & & $\begin{array}{l}\text { Sustainability } \\
\text { Mechanism }\end{array}$ & $\begin{array}{l}\text { - Continuity and follow up of the } \\
\text { development process, as the concept of } \\
\text { sustainability means communication and } \\
\text { continuity. } \\
\text { Thus, it is not enough to carry out the } \\
\text { development process without being able to } \\
\text { maintain its continuity, as sustainability is } \\
\text { based on a foundation of non-crumbling } \\
\text { resources, where the vast majority of these } \\
\text { resources can be recycled indefinitely. }\end{array}$ \\
\hline & & $\begin{array}{l}\text { Mechanism of } \\
\text { maximizing } \\
\text { the } \\
\text { consistency of } \\
\text { interaction }\end{array}$ & $\begin{array}{l}\text { Clean energy technologies: } \\
\text { Where access to clean energy can be } \\
\text { expanded, such as solar energy, due to the } \\
\text { presence of sun light around the year in the } \\
\text { areas of new cities, in addition to the } \\
\text { abundance of wind energy in the desert. It } \\
\text { should be noted that solar energy can be } \\
\text { exploited during the day in the sunrise, } \\
\text { while, wind energy decreases during the } \\
\text { day, and is more active at night, leading to } \\
\text { the idea of integration between the two } \\
\text { systems. Thus, they can be harnessed to } \\
\text { provide cities with a clean energy supply } \\
\text { that causes no environmental pollution. } \\
\text { - Supporting projects, through providing } \\
\text { technologically and organizationally } \\
\text { advanced services, so that all the means of } \\
\text { initiating and embracing projects could be } \\
\text { provided in an integrated work system, to } \\
\text { overcome the problems that lead to their } \\
\text { failure. }\end{array}$ \\
\hline $\begin{array}{c}\text { Industrial } \\
\text { development } \\
\text { strategy }\end{array}$ & $\begin{array}{l}\text { Establishing factories in sites } \\
\text { with available materials to } \\
\text { reduce transportation and } \\
\text { depend on exports. } \\
\text { Upgrading the } \\
\text { technological level of the } \\
\text { community. } \\
\text { Expansion of participation of } \\
\text { the private sector in the } \\
\text { industry development. }\end{array}$ & $\begin{array}{l}\text { Colonization } \\
\text { mechanism }\end{array}$ & $\begin{array}{l}\text { - Exploitation of mineral wealth that is found } \\
\text { in most of the Egyptian desert adjacent to } \\
\text { new cities, through the creation of many } \\
\text { industries, such as limestone suitable for the } \\
\text { manufacture of cement, pure lime and the } \\
\text { desert argil that is used in manufacturing } \\
\text { clay brick, refractories and ceramics, in } \\
\text { addition to white sand, which is suitable for } \\
\text { the manufacture of glass, basalt rocks } \\
\text { suitable for the manufacture of rock bricks } \\
\text { and road pavements, and phosphate, used for } \\
\text { the manufacture of fertilizers. }\end{array}$ \\
\hline
\end{tabular}




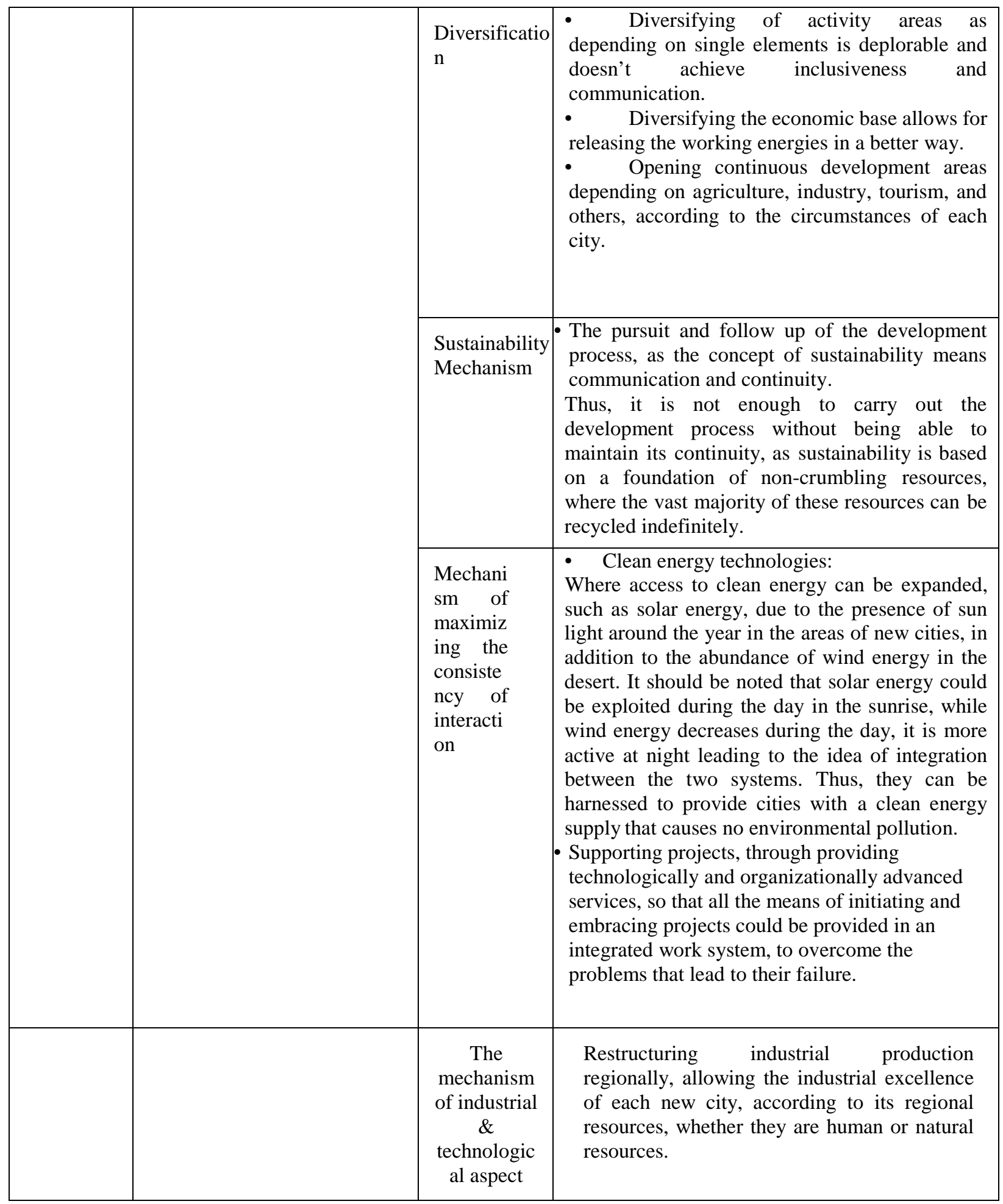




\begin{tabular}{|c|c|c|c|}
\hline $\begin{array}{c}\text { Tourism } \\
\text { development } \\
\text { strategy }\end{array}$ & $\begin{array}{l}\text { Establishing places of } \\
\text { relaxation, such as hotels and } \\
\text { campsites for those who seek } \\
\text { tranquility and enjoying } \\
\text { unique natural areas } \\
\text { Activating conferences } \\
\text { tourism and youth activities. }\end{array}$ & $\begin{array}{l}\text { Approximat } \\
\text { ion } \\
\text { Mechanism }\end{array}$ & $\begin{array}{l}\text { Developing the means of transportation } \\
\text { and reducing the distances between new } \\
\text { cities to eliminate the isolation between them } \\
\text { and the old valley, through some main axes, } \\
\text { including: } \\
\text { - Major road axes: represented in } \\
\text { strengthening the wild axes, connecting new } \\
\text { cities with the old valley and connecting } \\
\text { these cities together, in addition to providing } \\
\text { links and additional ways to enhance the } \\
\text { connection. } \\
\text { - Air transportation hubs: represented in } \\
\text { developing the existing airports and } \\
\text { establishing new ones. } \\
\text { - Telecommunications hubs: depends on } \\
\text { the establishment of a network of modern } \\
\text { communication lines. }\end{array}$ \\
\hline \multirow{3}{*}{$\begin{array}{c}\text { Social } \\
\text { development } \\
\text { strategy }\end{array}$} & \multirow{3}{*}{$\begin{array}{l}\text { Concerned with driving the } \\
\text { populations to new } \\
\text { communities, convincing } \\
\text { and encouraging them } \\
\text { to settle there and create the } \\
\quad \text { conditions that } \\
\text { ensure their stay in these new } \\
\text { places. }\end{array}$} & $\begin{array}{c}\text { Basic supports } \\
\text { Mechanism }\end{array}$ & $\begin{array}{l}\text { - Training and rehabilitation of the } \\
\text { citizens and organizing institutions } \\
\text { and civil organizations with } \\
\text { developmental or social objectives or } \\
\text { specific productivity that forms the } \\
\text { hidden dimension of management, } \\
\text { follow-up, planning and public } \\
\text { control, with no conflict, but rather } \\
\text { supports and integrates with } \\
\text { government systems responsible for } \\
\text { the central development. } \\
\text { Putting forward programs that aim to } \\
\text { increase humanitarian and social } \\
\text { activity in new cities, taking into } \\
\text { consideration the negative impacts of } \\
\text { the growth of an activity, while others } \\
\text { fade, be it commercial, industrial or } \\
\text { population activity. }\end{array}$ \\
\hline & & $\begin{array}{l}\text { Attribution } \\
\text { mechanism }\end{array}$ & $\begin{array}{l}\text { Promoting the sense of human } \\
\text { belonging and participating in } \\
\text { reclamation, construction, } \\
\text { construction management of different } \\
\text { projects in the new cities. } \\
\text { As human is the main element in the } \\
\text { establishment of new cities, preferably } \\
\text { young elements with different skills, } \\
\text { whose engagement with their new } \\
\text { communities can be a new beginning to } \\
\text { perform through a real sense of belonging. }\end{array}$ \\
\hline & & $\begin{array}{l}\text { Participation } \\
\text { Mechanism }\end{array}$ & $\begin{array}{l}\text { - The involvement of the private sector } \\
\text { and different organizations, even } \\
\text { individuals in the development } \\
\text { process. }\end{array}$ \\
\hline
\end{tabular}




\begin{tabular}{|c|c|c|c|}
\hline & & $\begin{array}{c}\text { Civil \& social } \\
\text { aspects mechanism }\end{array}$ & $\begin{array}{l}\text { - Co-ordination of work between the } \\
\text { civil organizations, interested in the } \\
\text { development of new cities and their } \\
\text { classification into groups according to } \\
\text { the interest such as health, society, } \\
\text { and small projects. } \\
\text { - Enhancing the role of NGOs and civil } \\
\text { society organizations in spreading the } \\
\text { concepts of preserving the natural } \\
\text { resources such as water, air, soil, and } \\
\text { energy sources. } \\
\text { Establishing regional systems of } \\
\text { certain environmental services, such } \\
\text { as health burial of solid waste or safe } \\
\text { disposal of wastes of all kinds. } \\
\text { Directing on supporting projects and } \\
\text { research, which aims for the } \\
\text { development of new cities. } \\
\text { Focus on the role of women in urban } \\
\text { environmental protection as a source } \\
\text { of awareness within the family. } \\
\text { Focus on development programs that } \\
\text { provide direct services to help people } \\
\text { settle in new cities, especially young } \\
\text { ones. } \\
\text { Coordinating efforts between the } \\
\text { associations and organizations } \\
\text { involved in urban development. }\end{array}$ \\
\hline \multirow[b]{2}{*}{$\begin{array}{c}\text { Population } \\
\text { attraction } \\
\text { strategy }\end{array}$} & \multirow[b]{2}{*}{$\begin{array}{l}\text { Providing economic } \\
\text { attraction factors such as job } \\
\text { opportunities and rewarding } \\
\text { salaries. In addition to the } \\
\text { social attraction factors such } \\
\text { as providing adequate } \\
\text { housing for young married } \\
\text { people and those seeking } \\
\text { marriage, especially for those } \\
\text { who can't afford adequate } \\
\text { housing in their original city. }\end{array}$} & $\begin{array}{l}\text { Basic supports } \\
\text { Mechanism }\end{array}$ & $\begin{array}{l}\text { Developing activities and functions } \\
\text { that maximize the ability of new cities } \\
\text { to attract residents and increase the } \\
\text { public city income. }\end{array}$ \\
\hline & & $\begin{array}{l}\text { Approximation } \\
\text { Mechanism }\end{array}$ & $\begin{array}{l}\text { Developing the means of } \\
\text { transportation and reducing the } \\
\text { distances between new cities to } \\
\text { eliminate the isolation between them } \\
\text { and the old valley, through some } \\
\text { main axes, including: } \\
\text { Major road axes: represented in } \\
\text { strengthening the wild axes, } \\
\text { connecting new cities with the old } \\
\text { valley and connecting these cities } \\
\text { together, in addition to providing } \\
\text { links and additional ways to enhance } \\
\text { the connection. } \\
\text { Air transportation hubs: represented } \\
\text { in developing the existing airports } \\
\text { and establishing new ones. } \\
\text { Telecommunications hubs: depends } \\
\text { on the establishment of a network of } \\
\text { modern communication lines. }\end{array}$ \\
\hline
\end{tabular}




\begin{tabular}{|c|c|c|c|}
\hline & & $\begin{array}{l}\text { Population } \\
\text { Movement } \\
\text { mechanism }\end{array}$ & $\begin{array}{l}\text { Providing strong attraction elements } \\
\text { (economic, social and services), } \\
\text { providing uniqueness of jobs, } \\
\text { efficient performance, and abundance } \\
\text { of salary. } \\
\text { Providing job opportunities and } \\
\text { rewarding salaries, is fundamental for } \\
\text { activating the attraction towards new } \\
\text { cities, as the individual must prefer } \\
\text { this place to others. }\end{array}$ \\
\hline \multirow[b]{3}{*}{$\begin{array}{c}\text { Urban } \\
\text { Development } \\
\text { Strategy }\end{array}$} & \multirow{3}{*}{$\begin{array}{l}\text { - Can be achievedby avoiding } \\
\text { the establishment of urban } \\
\text { communities in arable areas, } \\
\text { or those containing mineral } \\
\text { resources, or in sand dunes, } \\
\text { storm water drains, or } \\
\text { protectorates. } \\
\text { - The design of buildings } \\
\text { must consider harsh climate } \\
\text { conditions of heat and } \\
\text { humidity, through selecting } \\
\text { convenient building } \\
\text { m a ter i a l s and a suitable } \\
\text { design concept for the } \\
\text { environment. }\end{array}$} & $\begin{array}{l}\text { Population } \\
\text { Movement } \\
\text { mechanism }\end{array}$ & $\begin{array}{l}\text { - Providing strong attraction elements } \\
\text { (economic, social and services), } \\
\text { providing uniqueness of jobs, efficient } \\
\text { performance, and abundance of } \\
\text { salary. } \\
\text { - Providing job opportunities and } \\
\text { rewarding salaries, is fundamental for } \\
\text { activating the attraction towards new } \\
\text { cities, as the individual must prefer } \\
\text { this place to others. }\end{array}$ \\
\hline & & $\begin{array}{l}\text { Basic supports } \\
\text { Mechanism }\end{array}$ & $\begin{array}{l}\text { - Diagnosis of the current situation } \\
\text { socially, culturally economically, and } \\
\text { urban-wise and identifying buildings' } \\
\text { conditions and occupancy rates and } \\
\text { extent of the need for additional } \\
\text { elements of the infrastructure. }\end{array}$ \\
\hline & & $\begin{array}{c}\text { Resource } \\
\text { Occupation } \\
\text { Legislation \& } \\
\text { administration } \\
\text { mechanism }\end{array}$ & $\begin{array}{l}\text { - Thorough understanding of the } \\
\text { potential of the resources and putting } \\
\text { them in the right place. For example, } \\
\text { establishing factories on arable lands } \\
\text { are forbidden, and the areas rich in } \\
\text { historical elements should not be used } \\
\text { for agricultural. } \\
\text { - Following accurate scales to measure } \\
\text { the inputs and outputs to achieve } \\
\text { minimum losses against biggest gains. } \\
\text { - Liberalization of financing methods } \\
\text { development projects in new cities. } \\
\text { Liberalization of labor heads of the } \\
\text { central leaders and centralized } \\
\text { decision making. } \\
\text { Legalization of certain activities and } \\
\text { uses of new cities and activating laws } \\
\text { related to the prohibition of } \\
\text { establishing structures and industrial } \\
\text { activities inside or near urban } \\
\text { communities. } \\
\text { The provision of the required land for } \\
\text { various activities, in addition to the } \\
\text { provision of facilities, incentives, and } \\
\text { exemptions to speed up the } \\
\text { development process. }\end{array}$ \\
\hline
\end{tabular}




\section{Conclusion:}

The success of the new cities is dependent on its own development's policy. In addition, the implementation of this policy is set in accordance with specific strategies and mechanisms that allow them to exploit resources and facilities available for achieving the target of the planned policy.

\section{References:}

1. Abdel Moneim, M. N. (2008). Development of new urban communities, "The Egyptian State and International Experiences"(Unpublished doctoral dissertation, 2008). Faculty of Engineering, Cairo University.

2. Abdel Fattah, H. S. (2009). The State of New Cities of the Arab Republic of Egypt Case(Unpublished doctoral dissertation, 2009). Faculty of Engineering: Cairo University, 2009.

3. Abdel-Qader, L. A. (2005). An Analytical Study of the Problems of Development in the New Cities in Egypt(Unpublished doctoral dissertation, 2005). Faculty of Engineering, Cairo University.

4. Abdel Aal, A.M. (1992), Ahmed Mohammed. A Book of New Cities and Regional Development in Egypt, Magazine of the Faculty of Arts, Minya University

5. Abbas, A.M., (2007) The Development of Cities and Regions Random, Azhar Ninth International Engineering Conference.

6. Amin, M. (2009). The Functional Roles of Cities and New Communities within the Framework of National and Regional Policies Comprehensive Urban Development. The International Congress of the policies of the New Urban Communities Development.

7. Barakat, S. A. (2007). Evaluation of Urban Development Techniques for New Rallies in Egypt, with Special Mention of the Cities: (Tenth of Ramadan - Sadat - 6th of October 6)(Unpublished doctoral dissertation, 2007). ), Faculty of Engineering: Cairo University.

8. Shiha, S.M., (2007), The Role of Public Opinion Polls in Policy-making. The International Conference on Public Opinion Polls and Decision-making.

9. El Wakeel, S. (2006), Urban Planning "Principles - basics - applications ", the first edition 